\title{
Pollen morphology of Polish native species of the Rosa genus (Rosaceae) and its relation to systematics
}

\author{
Dorota Wrońska-Pilarek* \\ Department of Forestry Natural Foundations, Poznań University of Life Sciences, Wojska Polskiego 71d, 60-625 Poznań, Poland
}

\section{Abstract}

The morphology of pollen grains of 16 species from the Rosa L. genus were studied (i.e. R. agrestis, $R$. canina, $R$. dumalis, $R$. gallica, $R$. inodora, $R$. jundzillii, $R$. kostrakiewiczii, $R$. majalis, $R$. micrantha, $R$. mollis, $R$. pendulina, $R$. rubiginosa, $R$. sherardii, $R$. tomentosa, $R$. villosa, and $R$. zalana). The material came from 16 native localities of those species in Poland. The measurements are based on at least 30-50 randomly selected, fully developed pollen grains per specimen. In total, 500 pollen grains were examined. They were analysed for 13 quantitative features of pollen grains and exine sculpturing and the following qualitative traits: outline, shape, "operculum" structure. The diagnostic features of pollen grains of studied species were: length of polar and equatorial axes and length of ectocolpi. The above-mentioned pollen grain morphological features make isolation of one species possible: R. gallica. R. gallica is distinguished for its highest values of the length of polar and equatorial axes, and the length of ectocolpi. The obtained analytical results of operculum and exine sculpture features, considered as diagnostic, corroborated only slightly their priority significance for the isolation of the examined species and sections. The collected data failed to confirm fully the current taxonomical division of the Rosa genus into sections (only section Gallicanae from R. gallica is isolated) as well as consanguinity relationships between the examined species from the Caninae section. On the dendrogram, both species closely related with each other as well as those from other developmental lines were found in the same group. These equivocal results are by no means surprising because the Caninae section is the most polymorphic group in the Rosa genus, and contemporary Caninae are of the nature of a swarm of R. canina hybrids as a link combining all taxons of the section.

Keywords: Pollen morphology, Rosa, Caninae, Gallicanae, taxonomy

\section{Introduction}

The Rosa L. genus constitutes one of 36 European genera in the Rosaceae family [1]. The genus contains, depending on the adopted approach, 100 to 120 , or even 250 species and is distributed in the northern hemisphere in Europe, Asia, Ethiopia, the Middle East and North America [2-6].

According to Klaštersky [1], 47 rose species deriving from 5 sections grow currently in Europe. Henker [5] claims that, depending on the approach, 30 to 60 species from the Rosa genus occur in Europe, of which 33 species can be found in Central Europe. The majority of European roses, including the studied species, belong to the Caninae section [1,5,7].

Zieliński [3,7], who follows the concept of broad approach to species, mentions 14 rose species from Poland which represent the following three sections: Caninae (11 species), Rosa

\footnotetext{
*Email: pilarekd@up.poznan.pl

This is an Open Access digital version of the article distributed under the terms of the Creative Commons Attribution 3.0 License (creativecommons.org/licenses/ by/3.0/), which permits redistribution, commercial and non-commercial, provided that the article is properly cited.
}

(2 species), and Gallicanae (1 species), whereas Popek [8] enumerates 16 species including the Caninae section also $R$. kostrakiewiczii and $R$. mollis. Nearly all (15) of these species occur naturally in Central Europe [5]. The only exception is an endemic R. kostrakiewiczii Popek reported by Popek [8] from a single site situated in south-eastern Poland in the Góry Pieprzowe near Sandomierz $\left(50^{\circ} 40^{\prime} \mathrm{N} / 21^{\circ} 45^{\prime} \mathrm{E}\right)$.

The Rosa L. genus belongs to a group of plants which are critical and systematically more complex. Among the most important causes of the polymorphism observed in this genus are: hybridisation, polyploidy and - especially in the Caninae section - the mechanism of cytotype stabilisation of odd chromosome numbers resulting from the specific course of the so called Caninae type meiosis $[7,9,10]$.

Palynological investigations of the Rosa L. genus were carried out by numerous researchers and their beginnings go back to the end of the 19th century $[8,11-46]$.

Despite numerous publications, our knowledge about the structure of rose pollen grains is fragmentary because the available descriptions usually refer to one or several selected taxons or researchers analyse few selected pollen features. At the present time, in their investigations on pollen morphology of genus Rosa, palynologists focus on detailed analyses of exine sculpture features considered to be the most important distinguishing characters in Rosa pollen grains [8,27,35,36,38].

In the course of this study, pollen grain morphology of 16 
Tab. 1 Location of studied pollen samples of Rosa.

\begin{tabular}{|c|c|c|c|}
\hline Species & Localities & Position & Collector, herbarium \\
\hline R. agrestis Savi* & Prov. Świętokrzyskie, Pieprzowe Mts, near Sandomierz & $50^{\circ} 41^{\prime} \mathrm{N} / 21^{\circ} 45^{\prime} \mathrm{E}$ & Wrońska-Pilarek D; POZNF \\
\hline R. canina L.* & Prov. Mazowieckie, Kabacki Forest near Warszawa & $52^{\circ} 14^{\prime} \mathrm{N} / 21^{\circ} 01^{\prime} \mathrm{E}$ & Dmowska H; UW \\
\hline R. dumalis Bechst.* & Prov Lubuskie, Cigacice & $52^{\circ} 02^{\prime} \mathrm{N} / 15^{\circ} 37^{\prime} \mathrm{E}$ & Wrońska-Pilarek D; POZNF \\
\hline R. gallica L. ${ }^{* *}$ & Prov. Dolnośląskie, Koskowice & $51^{\circ} 11^{\prime} \mathrm{N} / 16^{\circ} 14^{\prime} \mathrm{E}$ & Szlachetka A, Wrońska-Pilarek D; POZNF \\
\hline R. inodora Fr. ${ }^{*}$ & Prov. Małopolskie, near Ostra Skała, Pieniny Mts & $49^{\circ} 24^{\prime} \mathrm{N} / 20^{\circ} 23^{\prime} \mathrm{E}$ & Szeląg Z; KRAM \\
\hline R. jundzillii Besser* & Prov. Dolnośląskie, between Wołów and Krzywlina Mała & $51^{\circ} 21^{\prime} \mathrm{N} / 16^{\circ} 39^{\prime} \mathrm{E}$ & Zieliński J; KOR \\
\hline R. kostrakiewiczii Popek* & Prov. Świętokrzyskie, Pieprzowe Mts, near Sandomierz & $50^{\circ} 41^{\prime} \mathrm{N} / 21^{\circ} 45^{\prime} \mathrm{E}$ & Popek R, Wrońska-Pilarek D; POZNF \\
\hline R. majalis Herrm.** & Prov. Świętokrzyskie, Białogońska Góra, Białogon & $50^{\circ} 51^{\prime} \mathrm{N} / 20^{\circ} 33^{\prime} \mathrm{E}$ & Kazanowski K; KOR \\
\hline R. micrantha Borrer ex Sm.* & Prov. Lubuskie, Połęcko & $52^{\circ} 03^{\prime} \mathrm{N} / 14^{\circ} 54^{\prime} \mathrm{E}$ & Boratyński A, Zieliński J; KOR \\
\hline R. mollis Sm.* & Prov. Podlaskie, Leśna & $51^{\circ} 01^{\prime} \mathrm{N} / 15^{\circ} 16^{\prime} \mathrm{E}$ & Sokołowski A; KRAM \\
\hline R. pendulina L.** & Prov Małopolskie, Nosal, Tatra Mts. & $49^{\circ} 14^{\prime} \mathrm{N} / 19^{\circ} 58^{\prime} \mathrm{E}$ & Wrońska-Pilarek D; POZNF \\
\hline R. rubiginosa $\mathrm{L}^{*}$ & Prov. Dolnośląskie, Ostrowąsy, near Milicz & $51^{\circ} 36^{\prime} \mathrm{N} / 17^{\circ} 29^{\prime} \mathrm{E}$ & Kaczmarek C; KRAM \\
\hline R. sherardii Davies* & Prov Lubuskie, Cigacice & $52^{\circ} 02^{\prime} \mathrm{N} / 15^{\circ} 37^{\prime} \mathrm{E}$ & Wrońska-Pilarek D; POZNF \\
\hline R. tomentosa Sm. ${ }^{*}$ & Prov. Podkarpackie, Besko & $49^{\circ} 36^{\prime} \mathrm{N} / 21^{\circ} 57^{\prime} \mathrm{E}$ & Wrońska-Pilarek D; POZNF \\
\hline R. villosa $\mathrm{L}^{*}$ & $\begin{array}{l}\text { Prov. Wielkopolskie, between Mełpin and Kadzewo, near } \\
\text { Dolsk }\end{array}$ & $52^{\circ} 01^{\prime} \mathrm{N} / 17^{\circ} 00^{\prime} \mathrm{E}$ & Wrońska-Pilarek D; POZNF \\
\hline R. zalana Wiesb.* & Prov. Lubuskie, Rudnica & $52^{\circ} 36^{\prime} \mathrm{N} / 15^{\circ} 12^{\prime} \mathrm{E}$ & Boratyński A, Zieliński J; KOR \\
\hline
\end{tabular}

${ }^{\star}$ Species from section Caninae DC. em. Christ. ${ }^{*}$ Species from section Cinnamomeae DC. ${ }^{* *}$ Species from section Rosa L. PZNF - Herbarium of Department of Forestry Natural Foundations University of Life Sciences in Poznań; UW - Herbarium of Warsaw University; KRAM Herbarium of Institute of Botany in Krakow; KOR - Herbarium of Institute of Dendrology in Kórnik.

rose species (Tab. 1) - i.e. all species which have their natural sites in Poland (according to Popek [8]) - were investigated. The above roses belong to the following three sections: Caninae, Rosa and Gallicanae [3,5].

The objective of the described investigations was to verify taxonomic usefulness of the examined pollen morphological attributes of 16 domestic rose species, with a special emphasis on exine sculpture and operculum structure features considered as diagnostic. The investigations were conducted using LM and SEM with the aim to check their usefulness for distinguishing sections and individual species from the Rosa genus. The interspecific differentiation of the analysed features has been also studied by using statistical methods. Palynological investigations based on such numerous quantitative and qualitative pollen grain features (over 20 features) have not been presented in formerly published literature with reference to the Rosa genus.

\section{Material and methods}

The pollen grains were collected in Poland, from 16 localities in the wild (Tab. 1). Some to several randomly selected flowers were collected from each individual (rose bush). The measurements are based on at least 30-50 fully developed pollen grains per specimen. In total, 500 pollen grains were analysed. They were analysed for 13 quantitative features of pollen grains and exine sculpturing and the following qualitative ones: outline, shape, "opercula" structure (Tab. 2). The structures described as "opercula" refer to a distinctly delimited sexine/ectexine structure which covers part of an ectoaperture and which is completely isolated from the rest of the sexine [47]; there can be, in some cases, no real opercula, but bulges of the intine at the beginning of pollen tube germination. Despite the above reservations, the term "operculum" is employed in this study as it is used by all palynologists who have described this structure so far $[8,18,19,27,32,33,36,37,40]$.

Exine sculpture elements were measured on the area of 25 $\mu \mathrm{m}^{2}$ in accordance with the methods of Ueda and Okada [48] and Ueda and Tomita [35].

All samples were acetolysed according to Erdtman's method [16], slightly modificated by Wrońska-Pilarek [49]. The terminology follows Punt et al. [50] and Hesse et al. [51]. The observations were carried out both with light microscope (Biolar 2308, Nikon HFX-DX) and scanning electron microscope (ISI 60, Zeiss $435 \mathrm{VP})$.

The empirical data from grain measurements embraced quantitative features (Tab. 2) Their analysis included descriptive statistics and correlation coefficients, univariate analysis of variance and Tukey's test, agglomerative grouping by Ward's

Tab. 2 Pollen grains features analysed.

\section{No. Features}

$\begin{array}{ll}1 & \text { Length of polar axis (P) } \\ 2 & \text { Length of equatorial axis (E) } \\ 3 & \text { Thickness of exine along polar axis (Exp) } \\ 4 & \text { Thickness of exine along equatorial axis (Exe) } \\ 5 & \text { Length of ectocolpi (Le) } \\ 6 & \text { P/E ratio } \\ 7 & \text { Relative thickness of exine (P/Exp ratio) } \\ 8 & \text { Relative thickness of exine (E/Exe ratio) } \\ 9 & \text { Number of perforations (Np) } \\ 10 & \text { Total area of perforations (Ap) } \\ 11 & \text { Number of muri (Nm) } \\ 12 & \text { Width of muri (Wm) } \\ 13 & \text { Width of striae (Ws) }\end{array}$



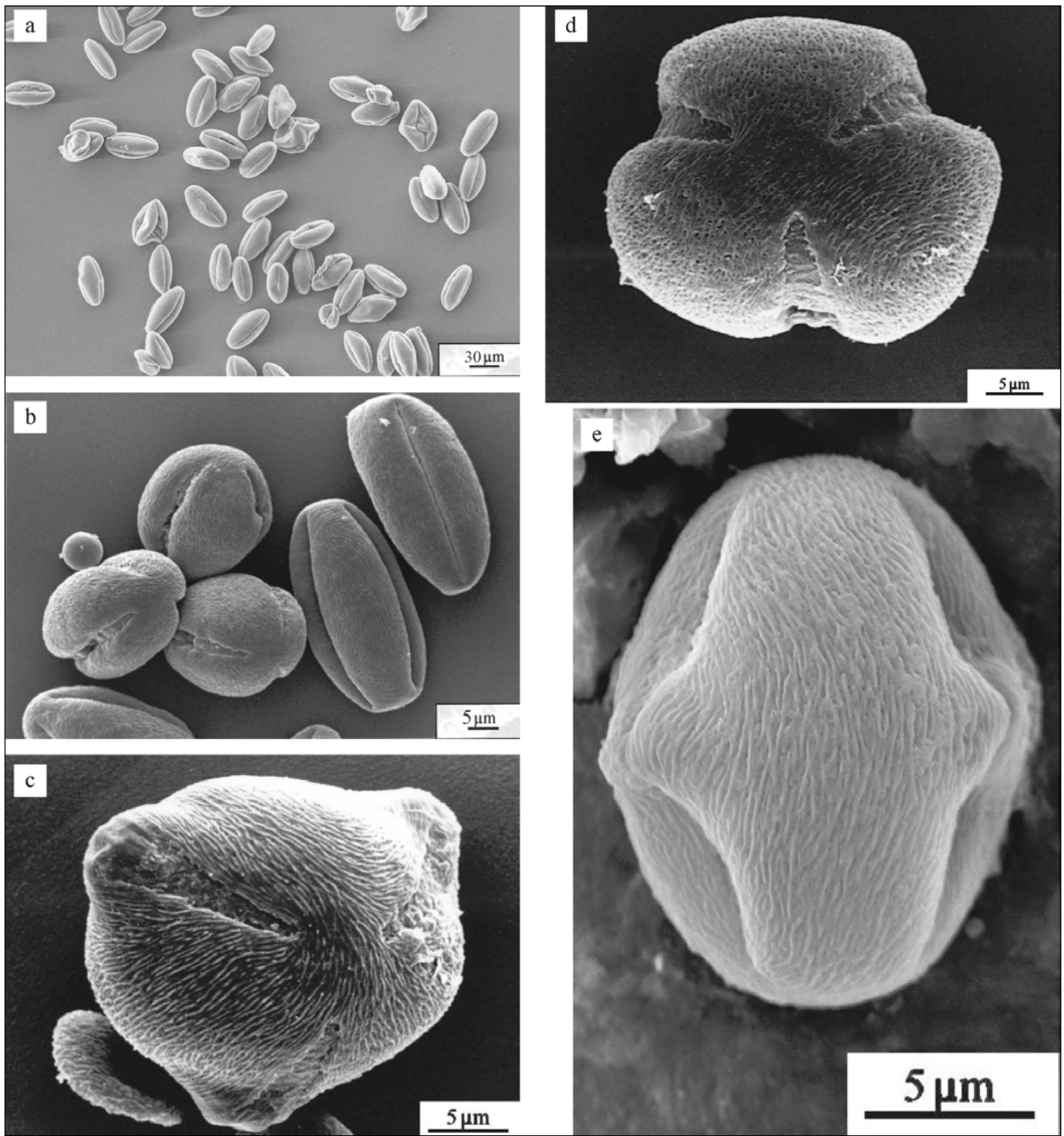

Fig. 1 SEM micrographs of pollen grains of studied Rosa species. a,b R. gallica, R. pendulina, respectively. Large, fully developed pollen grains and much smaller, not completely developed pollens in polar and equatorial view. $\mathbf{c}$. indora. Pollen grains in polar view - polar area, three ectocolpi and opercula visible. $\mathbf{d}$ R. pendulina. Pollen grains in polar view - polar area and three ectocolpi visible. e $R$. agrestis. Pollen grain in equatorial view - two ectocolpi with bridge visible.

method. Statistical analyses were performed using JMP 8.0 (SAS Institute Inc., Cary, NC, USA).

\section{Results}

\section{General pollen morphological description}

The grains of the studied Rosa species are: 3 - zonocolporate (all species), rarely 4 - zonocolporate (e.g. R. canina, R. jundzillii, R. micrantha), isopolar (Fig. 1c,d, Fig. 2a).
Apart from fully developed pollen grains, also much smaller, not completely developed pollen were found in the samples of the examined species (Fig. 1a,b). The majority pollen, according to Erdtman's [16] pollen size classification, is medium (25-50 $\mu \mathrm{m} ; 92.7 \%)$, rarely small $(10-25 \mu \mathrm{m} ; 7.3 \%)$. On average, the largest pollen were found in R. gallica (35.5 $\mu \mathrm{m})$, while the smallest - in $R$. majalis $(27 \mu \mathrm{m})$. The greatest numbers of small pollen grains were determined in samples of R. kostrakiewiczii (36.7\% of measured pollen) and in R. majalis (20\%); in samples of some other species (R. inodora, $R$. micrantha, $R$. sherardii) $6.7 \%$ to $10 \%$ (R. mollis, $R$. pendulina, $R$. 

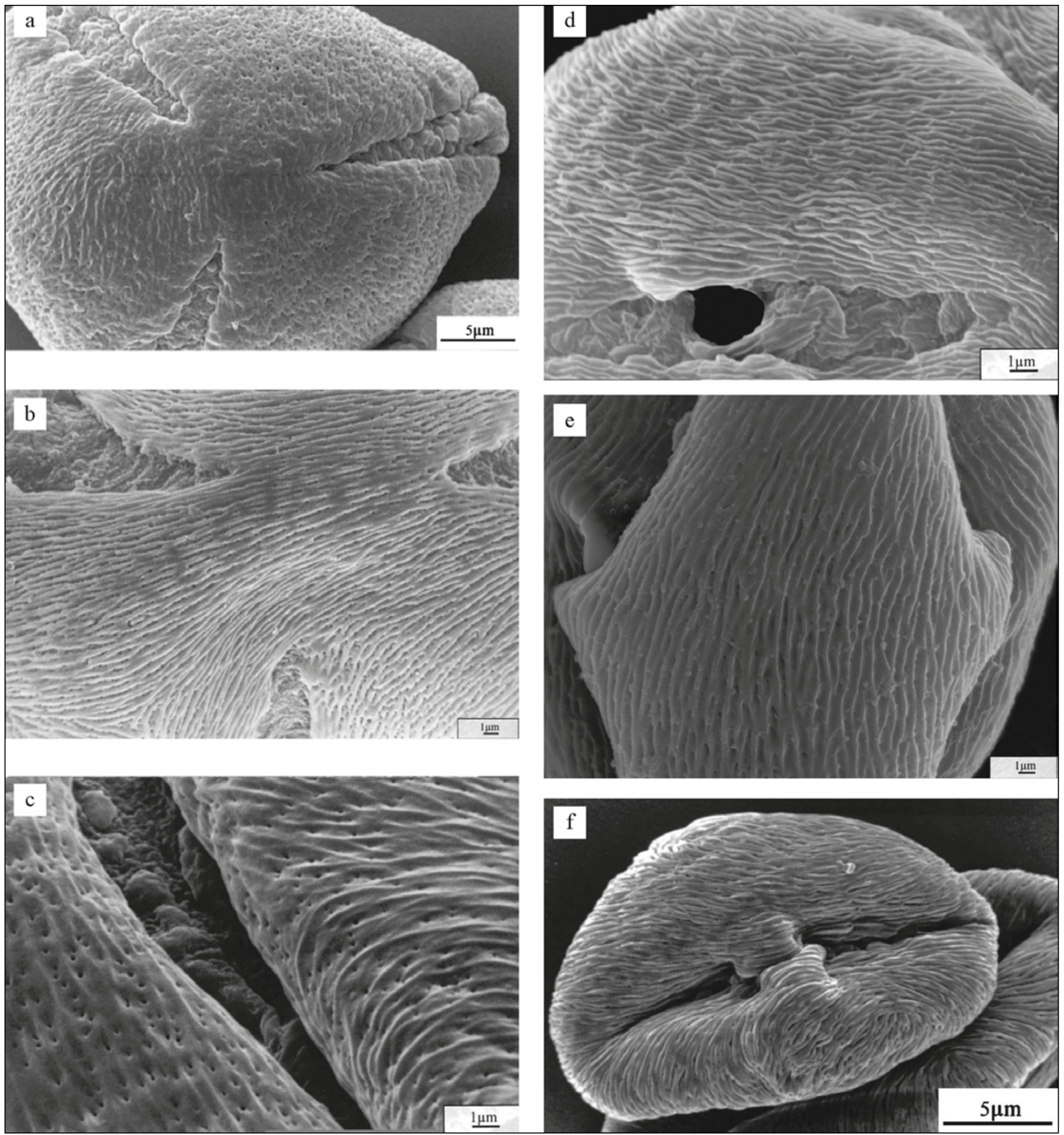

Fig. 2 SEM micrographs of pollen grains of studied Rosa species. a $R$. pendulina. Pollen grain in polar view - polar area and three ectocolpi visible. $\mathbf{b}$ R. gallica. Polar area and three ectocolpi visible. $\mathbf{c}$ R. jundzillii. Granulate ectocolpus and striate exine sculpture visible. $\mathbf{d}$ R. agrestis. Ectocolpus with opened endoporus visible. e,f $R$. majalis, $R$. canina, respectively. The bridge visible.

zalana) small pollen were found.

The average length of polar axes (P) amounted to 29.17 (24-36) $\mu \mathrm{m}$. The shortest average pollen axes $\mathrm{P}$ were found in $R$. inodora, $R$. kostrakiewiczii, $R$. majalis and R. zalana (21.6 $\mu \mathrm{m}$ each), while the longest ones - in R. gallica $(41.4 \mu \mathrm{m})$. The mean length of equatorial axes (E) amounted to 22.93 (16.234.2) $\mu \mathrm{m}$. On average, the shortest equatorial axes were determined in R. inodora, $R$. kostrakiewiczii, $R$. micrantha, $R$. mollis and $R$. zalana pollen ( $16.2 \mu \mathrm{m}$ each), while the longest - in $R$. gallica $(34.2 \mu \mathrm{m})$.

Outline in polar view - mostly circular or triangular with obtuse apices, more rarely elliptic. In equatorial view - mostly elliptic, rarely circular (Fig. 1a-e, Fig. 3a-c).

The average P/E ratio was 1.24 and ranged from 0.84 in $R$. gallica to 1.77 in the same species. It is evident that $R$. gallica stood out in terms of very significant variability of the pollen shape. The majority of pollen of the examined species were subprolate $(55.42 \%)$, less frequently - prolate $(22.71 \%)$ and prolate-spheroidal (17.29\%), rarely - spheroidal (3.54\%) and oblate-spheroidal (1.04\%). Most of the prolate pollen were found in R. gallica (53.3\%) and R. majalis (50\%). Prolate-spheroidal and spheroidal pollen were found predominant (66.7\%) only in $R$. jundzillii.

Exine is two-layered, well marked in LM (Fig. 3a-c). 


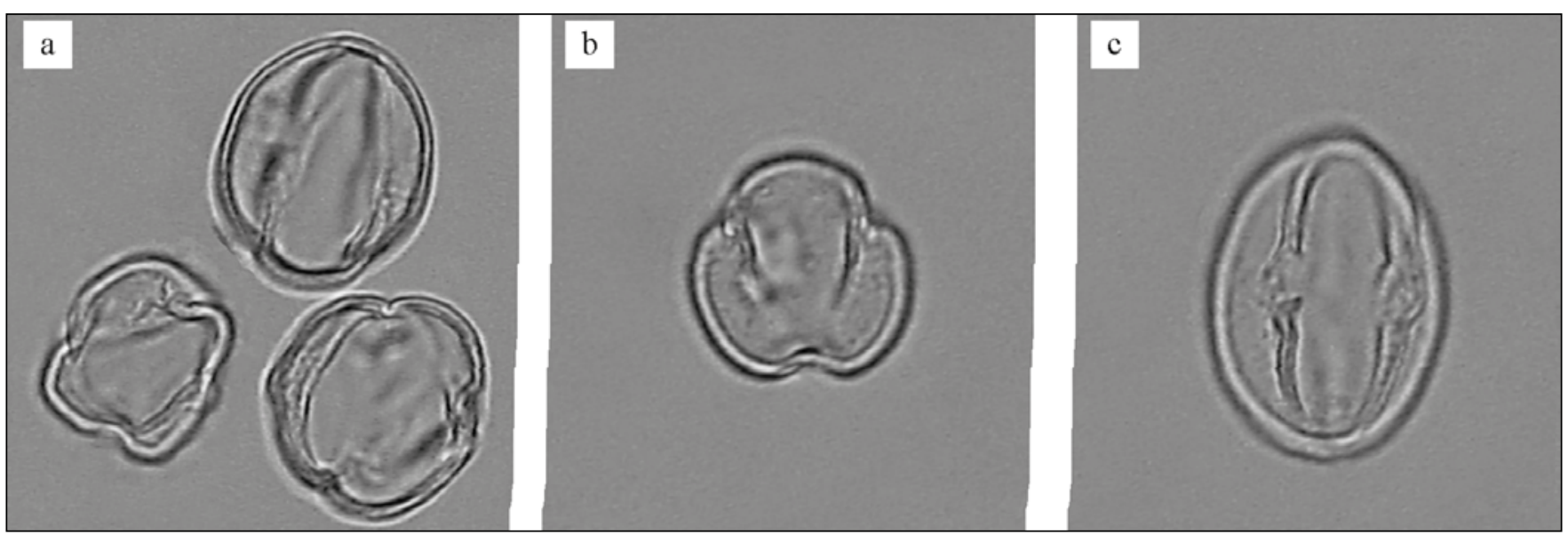

Fig. 3 LM micrographs of pollen grains of R. pendulina. a Three pollen grains in polar and equatorial view; exine visible. $\mathbf{b}$ Pollen grain in polar view; exine and two ectocolpi visible. c Pollen grain in equatorial view; exine and two ectocolpi visible.

Ectexine and endexine were usually of the same thickness, although sometimes ectexine was thicker. Mean exine thickness was found to be $1.61(0.9-1.98) \mu \mathrm{m}$. The thinnest exine was determined in $R$. mollis (on average: Exp-1.36 $\mu \mathrm{m}$; Exe-1.42 $\mu \mathrm{m}$ ), while the thickest - in $R$. canina (on average: Exp-1.8 $\mu \mathrm{m}$; Exe$1.8 \mu \mathrm{m})$. The relative thickness of the exine (Exp/P ratio) averaged 0.06 (0.03-0.08) and (Exe/E ratio) 0.07 (0.04-0.1). The above results are similar indicating more or less equal exine thickness along the entire pollen grain.

Exine sculpture - striate, variable, sometimes less, sometimes more distinct in LM. Muri usually ran parallel to the polar axis but frequently they also formed loops. They were straight or forked of varying length and width (Fig. 4a-f). On average, 11 muri were found on the area of $25 \mu \mathrm{m}^{2}$ and their numbers ranged from 8 ( $R$. dumalis, $R$. pendulina) to $13(R$. $j u n d z i l l i i, R$. sherardii). The widths of muri and striae were similar and averaged $0.26(0.14-0.40) \mu \mathrm{m}$ for muri and 0.25 $(0.09-0.45) \mu \mathrm{m}$ for striae. Part of the examined species (e.g. R. gallica, R. jundzillii, R. zalana) had muri and striae of similar width, while in others - either muri or striae were wider. The biggest differences between muri and striae widths were observed in $R$. mollis $(0.40 \mu \mathrm{m}, 0.09 \mu \mathrm{m})$ and $R$. inodora $(0.14$ $\mu \mathrm{m}, 0.45 \mu \mathrm{m}$; Tab. 3).

Circular or elliptic perforations of very different diameters (on average $-0.1-0.3 \mu \mathrm{m}$; ranging from 0.05 to $0.8 \mu \mathrm{m}$ ) were found at the bottom of striae (Fig. $4 \mathrm{a}-\mathrm{f}$ ). The mean number of those perforations on the area of $25 \mu \mathrm{m}^{2}$ amounted to 69.7 and ranged from 22 ( $R$. majalis) to 145 ( $R$. gallica), whereas the average area taken up by them amounted to $0.85 \mu \mathrm{m}^{2}$; ranging from $0.42 \mu \mathrm{m}^{2}$ (R. sherardii) to $2.16 \mu \mathrm{m}^{2}$ (R. canina). The examined species were assigned to 4 types of exine sculpture distinguished by Ueda [38]. Majority of them belong to II A type (R. canina, R. gallica, R. jundzillii, R. kostrakiewiczii, R. majalis, $R$. micrantha, $R$. mollis, $R$. pendulina, $R$. rubiginosa, $R$. tomentosa, $R$. villosa, $R$. zalana), others to II B type ( $R$. inodora, $R$. pendulina, $R$. sherardii, $R$. zalana), III A type ( $R$. agrestis, $R$. dumalis) and to III B type (R. agrestis, R. canina, R. dumalis, $R$. tomentosa).

Apertures 3, very rarely 4 ectocolpi and endopores. Usually one, rarely two endopores occurred in ectocolpi. Ectocolpi were arranged meridionally, regularly, more or less evenly spaced (Fig. 2a-d). They were long, with mean length of 22.49 $\mu \mathrm{m}$ ranging from $16.2 \mu \mathrm{m}$ ( $R$. inodora) to $32.4 \mu \mathrm{m}$ ( $R$. agrestis); on average, ectocolpi constituted $79.8 \%$ of the length of the polar axis. On average, the longest ectocolpi were determined in R. gallica pollen $(26.3 \mu \mathrm{m})$, while the shortest - in $R$. canina $(20.5 \mu \mathrm{m})$. Ectocolpi were acute and elliptic in outline. Widths were variable, usually greatest in the equatorial region with sculpturing of ectocolpus membrane approaching regulate. In some species (e.g. $R$. agrestis, $R$. canina, $R$. majalis, $R$. rubiginosa, $R$. tomentosa) ectocolpus crossed at the equator by a bridge dividing into two parts, formed by two intersecting bulges of ectexine (Fig. 2e,f). Bulges were of the same, or unequal length. Ectocolpus margins frequently with small undulations. Costae colpi present. Endopores (1, rarely 2) usually located in the middle of ectocolpi, readily visible after opening, with irregular margins (Fig. 2d). Fastigium present.

Operculum occurred usually in the central part of the ectocolpus, sometimes situated symmetrically; partially covering the ectocolpus. Usually, it was more or less a convex, elongated, exceptionally rosette-form structure (R. kostrakiewiczii; Fig. $5 a)$. Operculum may vary from convex, large (about 1/2-1/4

Tab. 3 Exine sculpture features analysed.

\begin{tabular}{lccccc} 
Species & $\mathbf{N p}$ & $\mathbf{A p}\left(\boldsymbol{\mu \mathbf { m } ^ { 2 }}\right) \mathbf{N m}(\boldsymbol{\mu m}) \mathbf{W m}(\boldsymbol{\mu m}) \mathbf{W} \mathbf{s}(\boldsymbol{\mu m})$ \\
\hline R. agrestis & 82 & 0.44 & 11 & 0.30 & 0.22 \\
R. canina & 73 & 2.16 & 12 & 0.18 & 0.29 \\
R. dumalis & 60 & 1.00 & 8 & 0.33 & 0.39 \\
R. gallica & 145 & 1.19 & 13 & 0.20 & 0.22 \\
R. inodora & 62 & 0.86 & 9 & 0.14 & 0.45 \\
R. jundzillii & 63 & 0.75 & 13 & 0.22 & 0.24 \\
R. kostrakiewiczii & 59 & 0.48 & 12 & 0.30 & 0.14 \\
R. majalis & 22 & 0.66 & 11 & 0.29 & 0.18 \\
R. micrantha & 85 & 0.44 & 10 & 0.30 & 0.12 \\
R. mollis & 64 & 0.75 & 10 & 0.40 & 0.09 \\
R. pendulina & 62 & 0.82 & 8 & 0.18 & 0.36 \\
R. rubiginosa & 64 & 1.47 & 9 & 0.23 & 0.32 \\
R. sherardii & 58 & 0.42 & 13 & 0.22 & 0.28 \\
R. tomentosa & 58 & 0.58 & 11 & 0.30 & 0.18 \\
R. villosa & 101 & 1.08 & 11 & 0.31 & 0.22 \\
R. zalana & 57 & 0.45 & 11 & 0.32 & 0.29 \\
\hline & & & & & \\
\hline
\end{tabular}

For feature names, see Tab. 2. 

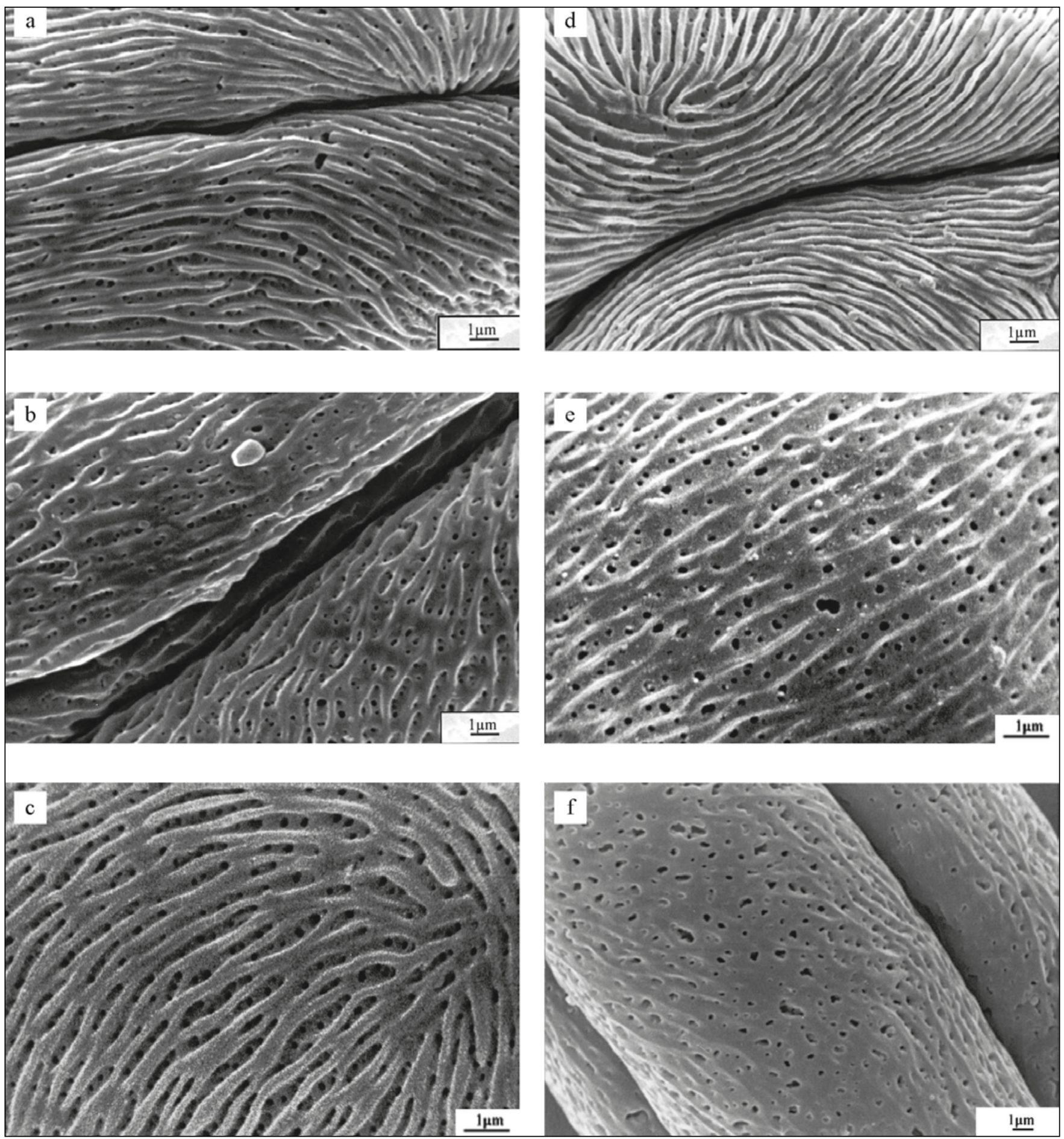

Fig. 4 SEM micrographs of a few striate exine sculpture types of studied Rosa species. a,b R. rubiginosa and R. dumalis, respectively. Muri clearly visible, quite high, numerous perforations with very different diameters. $\mathbf{c}$. gallica. Muri clearly visible, quite high, slightly flat, perforations with similar diameters. $\mathbf{d}$ R. zalana. Muri clearly visible, quite high, less numerous perforations, smaller with similar diameters. e,f $R$. inodora and R. pendulina, respectively. Muri lower and narrower, vanishing in some places, numerous perforations with very different and sometimes quite large diameters.

length of ectocolpus), wide (usually equal but sometimes wider than the width of ectocolpus; e.g. R. canina, R. gallica, R. inodora, R. jundzillii, R. kostrakiewiczii, R. majalis, R. micrantha, $R$. pendulina, $R$. tomentosa, $R$. zalana) to narrow (equal or narrower than the width of ectocolpus), elongated and flat in $R$. pendulina (Fig. 5b-f). Operculum sculpture usually psilate, less often striate; operculum surface often corrugated.

Despite the fact that the operculum structures of the examined species undergo certain variability, nevertheless all of them should be assigned to a type common for $R$. canina.
The author did not decide to classify the R. kostrakiewiczii as a separate type. To begin with, a rosette-like, irregularly formed structure was observed only in three out of 60 pollen grains examined specially from the point of view of this trait. In part of the remaining pollen, opercula of the structure similar to the remaining examined species occurred. Secondly, it is also possible that it is not a operculum but a bulging of the intine. Therefore, at the current stage of investigations, the presence of that structure in $R$. kostrakiewiczii cannot be considered as pollen diagnostic feature of this species. If detailed 

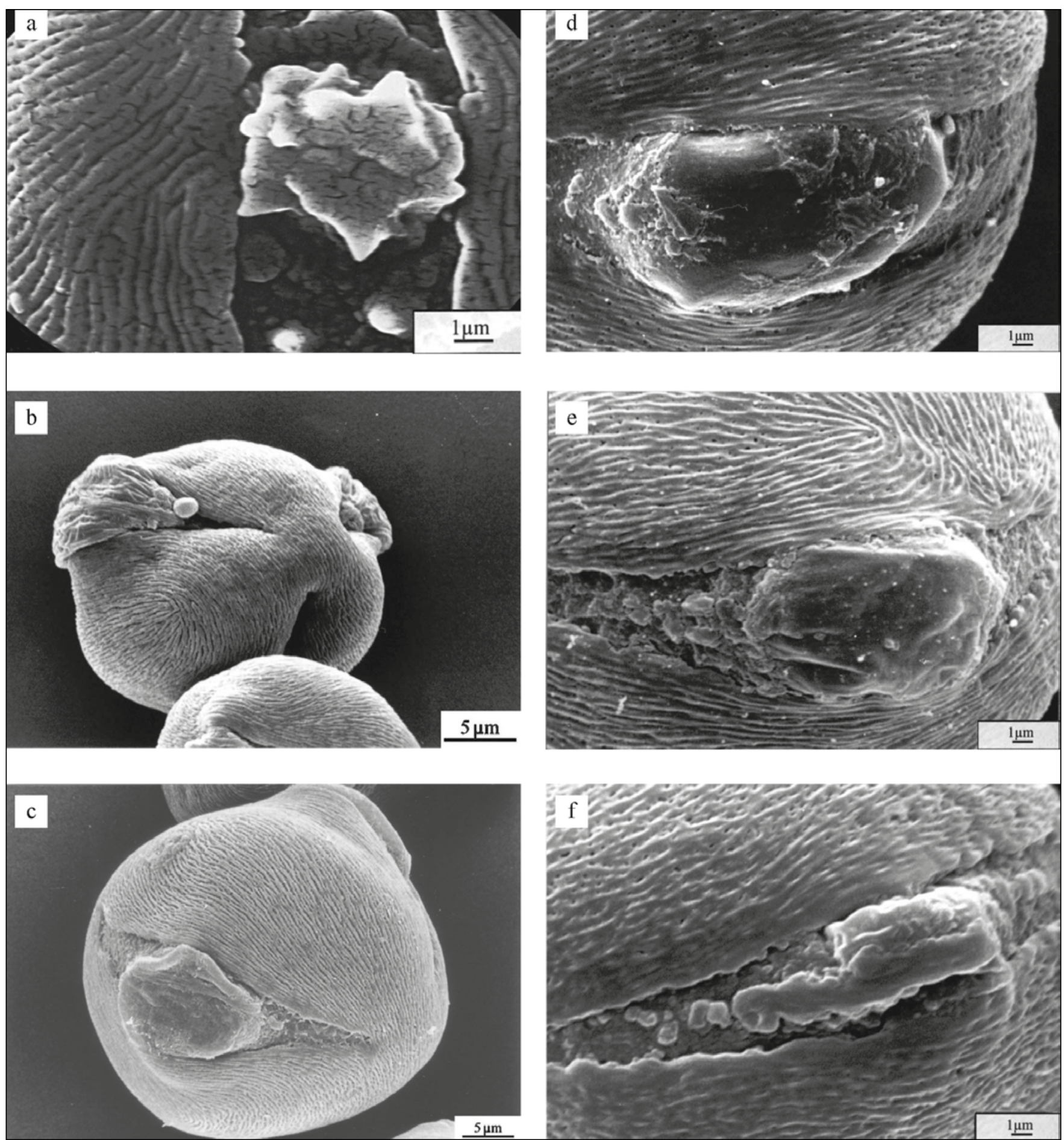

Fig. 5 SEM micrographs of pollen grains of studied Rosa species. a $R$. pendulina. Pollen grain in polar view - polar area and three ectocolpi visible. $\mathbf{b}$ R. gallica. Polar area and three ectocolpi visible. $\mathbf{c}$ R. jundzillii. Granulate ectocolpus and striate exine sculpture visible. $\mathbf{d}$ R. agrestis. ectocolpus with opened endoporus visible. e,f $R$. majalis, $R$. canina, respectively. The bridge visible.

morphological and anatomical studies of this structure confirm its presence, a separate operculum type - R. kostrakiewiczii may be established.

\section{Interspecific variability of pollen grains}

All the examined features were characterised by moderate variability. Mean coefficients of variability $(\mathrm{CV})$ calculated for the analysed pollen features of all experimental species amounted to: P - 11.3\%, E - 13.4\%, P/E - 11.9, Exp - 15.1\%, Exe - 13.9\%, Exp/P - 16.6\%, Exe/E - 18.4\%, Le - 11.3\%. P, E and Le features exhibited lower values of the coefficient of variability than exine thickness features (Exp, Exe, Exp/P, Exe/E).
R. mollis and R. kostrakiewiczii belong to species which show the highest values of the coefficient of variability with regard to all the examined pollen grain features, while e.g. R. pendulina and R. canina - to those with the lowest values (Tab. S1).

On the basis of the analysis of diagonal elements of the inverse matrix to the correlation matrix R for P, E, P/E, Exp, Exe, Exp/P, Exe/E and Le features, features with low values of the diagonal element which indicated a poor correlation of a given trait with the remaining ones were selected for further investigations. The following trait system of $\mathrm{P}-2.56, \mathrm{E}-1.48$, Exp 1.48, Exe -1.43 and Le -2.28 diagonal elements was selected.

In order to verify the presumption about dissimilarity of 
the examined pollen parameters in the 16 examined species, a single factorial analysis of variance was conducted. Assumptions about the normal distribution (Shapiro-Wilk test) and variance uniformity (Levene test) were verified. Due to the lack of homogeneity of the analysed attributes, a logarithmic transformation was employed. Analysing the empirical value of $F$-statistics and probability $p$ for each analysed attribute, significant differences at the significance level of $5 \%$ were found (feature $\mathrm{P}-\mathrm{F}_{\text {calc }}=24.70$ and $p=0.000$, feature $\mathrm{E}-\mathrm{F}_{\text {calc }}=21.75$ and $p=0.000$, feature $\operatorname{Exp}-\mathrm{F}_{\text {calc }}=6.63$ and $p=0.000$, feature Exe $-\mathrm{F}_{\text {calc }}=8.68$ and $p=0.000$ and feature Le $-\mathrm{F}_{\text {calc }}=11.39$ and $p=0.000)$. When analysing individual species (1-16), the absence of significant differences for each attribute was marked by two dots connected by a dashed line (Fig. 6).

It is evident from Fig. 3a that R. kostrakiewiczii exhibited the smallest pollen grains (features $P, E$ ), not very high mean exine thickness (features Exp, Exe) as well as one of the shortest ectocolpi (feature Le). Also R. mollis was characterised by low mean values of the examined characters. On the other hand, $R$. gallica showed the largest pollen (features P, E) and the longest ectocolpi (feature Le) accompanied by low and moderate mean values of the exine thickness (features Exp, Exe).

The above data were confirmed by the dendrogram obtained as a result of agglomeration grouping using Ward method (Fig.
7). R. gallica stands apart from all the remaining species which were assigned to one of the following three groups' the first group comprises $R$. mollis and R. kostrakiewiczii, the second $R$. majalis, $R$. zalana, $R$. micrantha, $R$. rubiginosa, $R$. inodora and R. canina, and the third - R. jundzillii, R. dumalis, R. villosa, $R$. tomentosa, $R$. sherardii, R. pendulina and R. agrestis.

\section{Discussion}

Morphological descriptions of pollen grains of the following examined species can be found in palynological literature: R. canina, R. gallica, R. majalis, $R$. micrantha, R. pendulina and $R$. rubiginosa $[19,21,22,26,27,31,33,44,45]$. They are similar to the descriptions presented in this article.

Shinwari and Khan [43] maintain that the palynological features of exine thickness, shape, length of equatorial and polar axes and length of ectocolpi were found useful criteria for species of genus Rosa delimitation; while sculpturing at LM turned out to be poor criteria. Results presented here corroborate this opinion only partly and indicate that among characters which allowed identification of some of the examined species were: length of polar and equatorial axes, length of ectocolpi and the operculum structure.

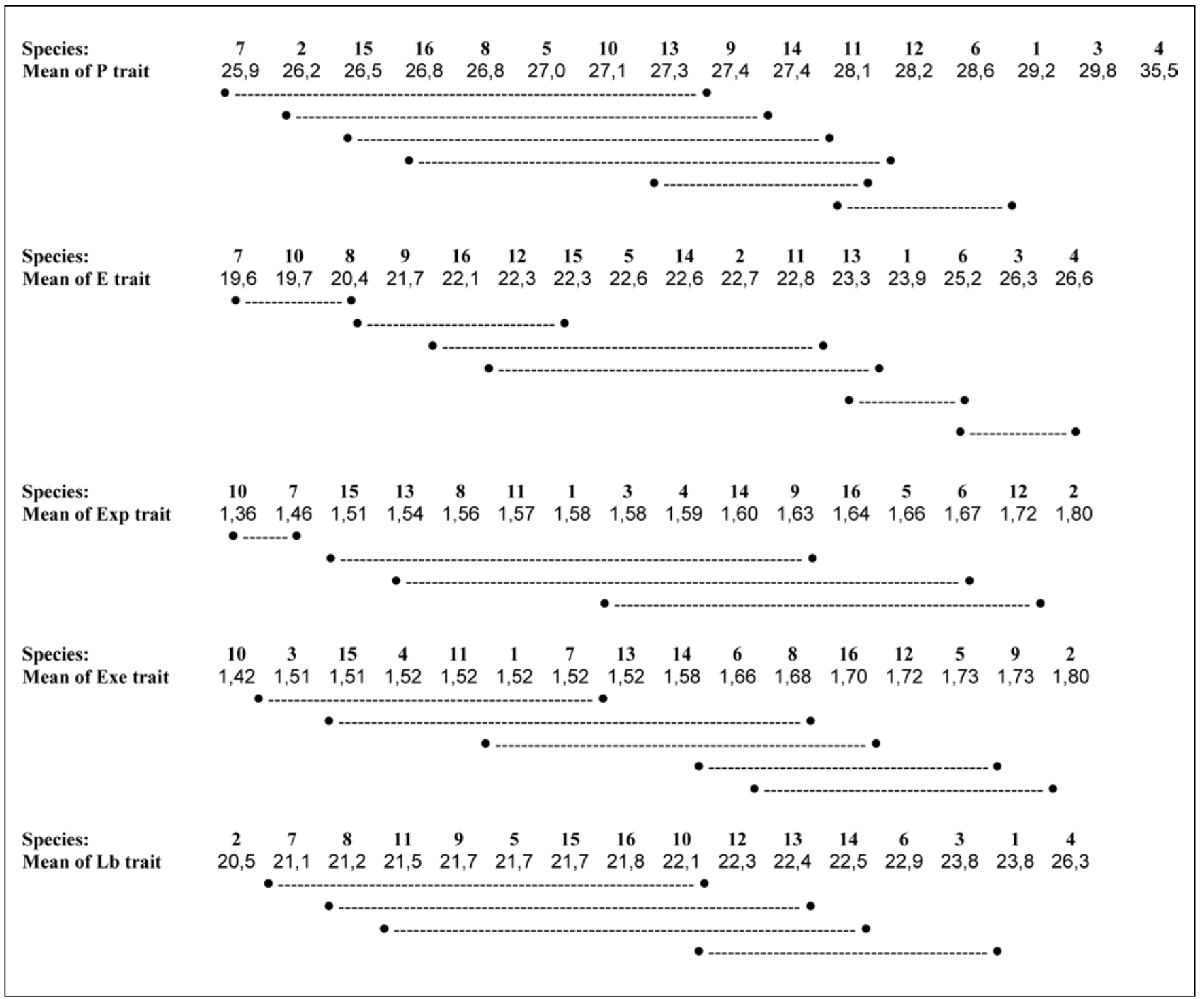

Fig. 6 Multiple comparisons by Tukey's test. 


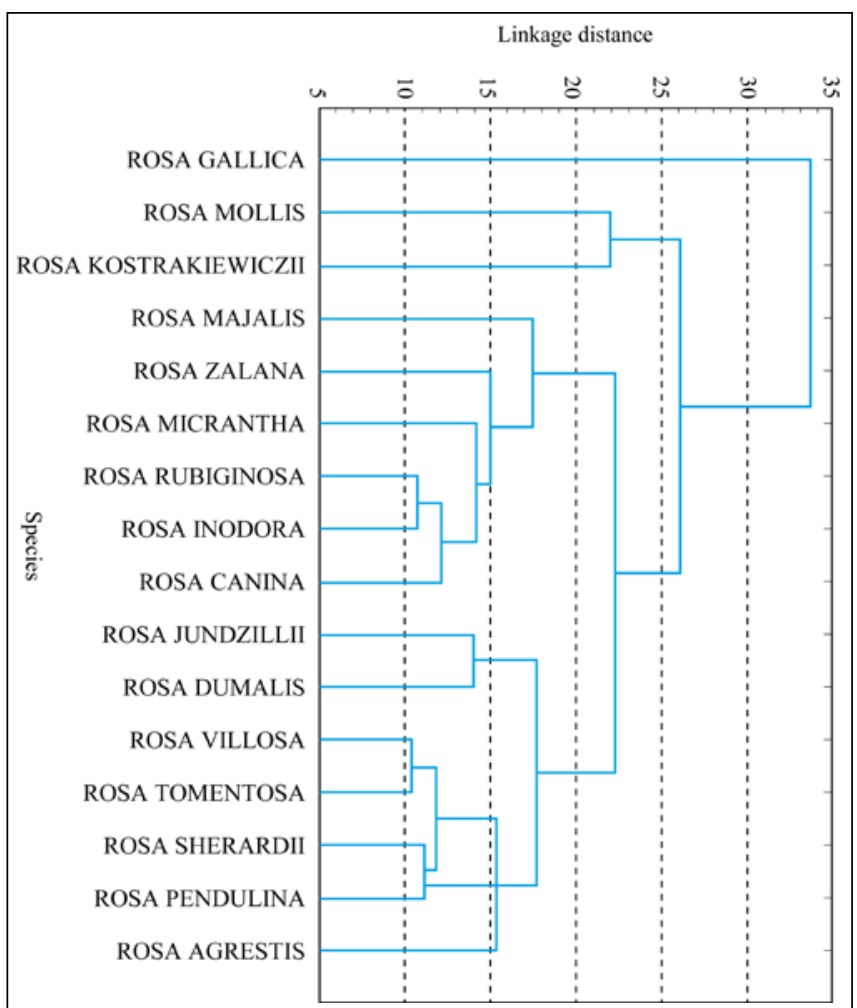

Fig. 7 Dendrogram of cluster groupings of 16 studied species on the basis of pollen grain morphological features.

Reitsma [19] showed that many north-western European rosaceous taxa could be separated on the basis of pollen morphology. He claims that among the most important attributes of Rosa pollen grains are: the type of exine sculpture as well as the presence or absence of costae colpi and operculum structure. On their basis, he distinguished the following three pollen grain types: $R$. gallica type, $R$. canina type and Rubus idaeus type, to which he also included $R$. rubiginosa, $R$. agrestis and $R$. rugosa. The results of this study corroborate the rightness of separation of R. gallica, although they do not justify the distinction of the two remaining types.

Also other palynologists confirm the diagnostic significance of the exine sculpture as a distinguishing attribute of Rosaceae pollen grains both at genus and species levels $[8,27,35,36,38]$. The most important features of exine sculpture include the number and size of perforations as well as the interval, number and diameter of striae [36,48,52-55]. Hebda and Chinnappa $[36,56]$ distinguished two types of perforations in Rosaceae (striate sculpturing macroperforate and non-striate sculpturing macroperforate, each with 6 subtypes) possibly pointing to different evolutionary lines. Roses were incorporated into the first type of large perforations often extending onto tectal striae. In addition, they also emphasised the fact that in Rosa, striae are long and parallel to ectocolpus. This classification was also corroborated by this study. According to the above researchers, pollen of Rosa (with Prunus, Rubus and Spirea) belong to the subcategory with striae separated by muri, containing larger perforations (0.1-0.2 $\mu \mathrm{m}$ in diameter). Investigation results presented here confirm this hypothesis with the reservation that, at such variability of perforation diameters as in the case of Rosa (ranging from 0.05 to $0.8 \mu \mathrm{m}$ ), it would perhaps be advisable to indicate that "larger" refers to medium diameter values of perforations. Menge [57], on the other hand, emphasises that the number of perforations is also an important trait of exine sculpture. The priority importance of this attribute was not corroborated by this study with regard to the examined species because majority (10) of the 16 examined species exhibited a similar number of perforations (57-64) on the area of $25 \mu^{2}$. On the other hand, values of this character varied considerably (from 22 perforations in $R$. majalis to 145 in R. gallica). Perforations also exhibited differences in their diameters and therefore, their numbers do not always correspond to the area they occupy (e.g. 22 perforations in $R$. majalis large enough to occupy the area of $0.66 \mu \mathrm{m}^{2}$, whereas in $R$. tomentosa and $R$. jundzillii, a similar area was taken up by 58 and 63 perforations, respectively).

Ueda and Tomita [35] examined pollen grain microstructure of 125 rose taxons and, on this basis, they distinguished 6 types and 3 subtypes of exine structure. Similar values of exine features were obtained in this study. This refers to numbers and area occupied by perforations as well as numbers and diameters of striae. These investigations were continued by Ueda [38] who classified rose species examined in this study into the following types: II A - R. canina, R. gallica, R. majalis, R. micrantha, $R$. mollis, $R$. pendulina, $R$. rubiginosa, $R$. tomentosa, II B - R. inodora, III A - R. villosa, III B - R. agrestis. In this study, these rose species were assigned to four types of exine sculpture (II A, II B, III A, III B) distinguished by Ueda [38]. Most of them were included in the same types as in the case of the above-mentioned researcher but two of them were allocated to other classes ( $R$. villosa - II A, R. agrestis - IIIA), while in several others, two types of exine sculptures (R. canina, R. dumalis, $R$. pendulina, $R$. tomentosa and $R$. zalana) were found which were not observed by Ueda [38].

Popek [8] described exine sculptures of 54 species and 12 varieties of roses belonging to 4 sub-genera. He distinguished sculpture reticulate and striate, the latter one with 11 subtypes (including $R$. gallica subtype). These investigations of exine sculpture elements failed to corroborate a separate identity of $R$. gallica exine sculpture. It is true that it had the highest number of perforations (145) of all the examined species occupying a relatively extensive area $\left(1.19 \mu \mathrm{m}^{2}\right)$, but similar results were obtained, for example, for R. villosa $\left(101,1.08 \mu \mathrm{m}^{2}\right.$; Tab. 3). The remaining attributes of $R$. gallica exine sculpture were the same as in the remaining species.

Recapitulating, the results of the presented investigations failed to confirm the diagnostic significance of exine sculpture attributes either at the level of species or section. The examined exine features did not allow identification of individual species because, for the majority of them, similar results were obtained. It happens that some species can be distinguished by one attribute (e.g. by a large number of perforations: $R$. gallica - 145 and $R$. villosa - 101 or their small numbers: $R$. majalis 22; or large area of perforations: $R$. canina $-2.16 \mu \mathrm{m}^{2}$ ), but the remaining exine sculpture features of these roses are similar to other species. It is only possible to identify groups of species of similar exine sculpture.

The performed analysis of operculum characters confirmed the significance of this trait only for the diagnosis of single species. Majority of the examined roses were characterised by opercula of similar structure. The taxonomic value of this attribute is diminished by the fact that, firstly, it underwent significant variability (e.g. two types of opercula were identified in $R$. pendulina) and, secondly, that pollen grains - with, as well as without - opercula occurred in majority of the examined species. The second of the above Rosa pollen features was reported by Reitsma [19] who classified R. canina and R. gallica 
as operculate, while $R$. rubiginosa, $R$. rugosa and $R$. arvensis - as deprived of operculum. Also Eide [27] observed that $R$. canina, $R$. pimpinellifolia and $R$. rubiginosa had pollen either with or without opercula and added that in R. canina, operculate pollen seem to be less frequent than pollen grains without opercula. Popek [8] distinguished 6 types of opercula in roses (including $R$. canina and $R$. kostrakiewiczii types) and his distinction of $R$. kostrakiewiczii type operculum was later corroborated (the only species with a rosette opercula). On the other hand, all the remaining rose species should be allocated to the $R$. canina operculum type proposed by him. Among interesting results of this study, not found in literature on the subject, was the identification in R. pendulina of two operculum types (wide and convex and narrow and flat). However, the diagnostic value of this attribute should be confirmed in further studies. Therefore, also Popek's [8] thesis claiming that two closely related species, namely, R. pendulina and $R$. majalis differed regarding operculum structure was not fully confirmed because part of the examined $R$. pendulina pollen grains had opercula with similar structure as in $R$. majalis. On the other hand, however, also narrow and flat opercula were identified in $R$. pendulina differing from those found in R. majalis.

Morphological structure of pollen grains by no means resolves the issue of the debaTab. taxonomical position of $R$. kostrakiewiczii and R. mollis. Popek [8] described R. kostrakiewiczii in the rank of species, whereas Zieliński [3] claims it is a sTab. hybrid between $R$. rubiginosa and $R$. agrestis. The pollen grain morphology, on the one hand, corroborates the first thesis because $R$. kostrakiewiczii differs from the remaining roses by the smallest pollen grains (it has the highest number $36.7 \%$ - of small pollen grains). Popek [8] observed in this rose also rosette-form, irregular structure which was described as a rosette-like operculum. Nevertheless, the results presented here indicate that at the current stage of investigations, this character cannot be considered as a diagnostic feature for pollen grains of that species. However, on the other hand, this species fails to exhibit other distinguishing attributes or common features with $R$. rubuginosa or $R$. agrestis pollen grains. In turn, $R$. mollis is included into R. villosa L. s. 1. [1,3] or treated as a separate species $[5,8]$. $R$. mollis and $R$. villosa pollen grains failed to show common features in a dendrogram. In addition, attributes of $R$. mollis pollen grains and its close morphological relative $-R$. sherardii - were not similar. Another interesting result of the performed statistical analyses included a separate identity of $R$. kostrakiewiczii and R. mollis visible on the dendrogram (Fig. 7) whose ambiguous taxonomical status is confirmed by the highest variability of pollen grains (Tab. S1). It is worth stressing that among lowest coefficients of variability were those determined in sexually reproduced $R$. canina and $R$. pendulina, often referred to as "good species". R. gallica pollen grains, also included in the latter group, revealed moderate variability.

The distribution of the examined species in the dendrogram confirms only slightly the currently adopted taxonomic division of the Rosa genus into sections [5]. R. gallica separated from the Gallicanae section. On the other hand, closely related $R$. pendulina and $R$. majalis from the Rosa section characterised by pollen grain features similar to roses from the Caninae section stand apart. This confirms Zieliński's [3,7] thesis about the absence of a definite morphological boundary between the Caninae section and groups that contributed to its development, especially the Rosa section.

Pollen morphological structure reflects only slightly consanguinity relationships between the examined species from the Caninae section described by Henker [5] and Zieliński [7]. According to Zieliński [7], R. canina was the "initial" species for this section. It is from here that six development lines run formed by R. judzillii, then by R. micrantha and $R$. rubiginosa, $R$. agrestis as well as $R$. inodora, $R$. tomentosa, $R$. sherardii and $R$. villosa and two single species $-R$. dumalis and $R$. glauca. On the dendrogram, both closely related species (e.g. $R$. tomentosa, R. sherardii and R. villosa) as well as those from different developmental lines (e.g. $R$. agrestis) can be found. $R$. canina pollen grain attributes are the closest to the features of $R$. inodora, R. rubiginosa (Fig. 7). These equivocal results are by no means surprising because the Caninae section is the most polymorphic group of the Rosa genus and the contemporary Caninae have the nature of a hybrids swarm with $R$. canina as a link connecting all section taxons $[3,7]$.

\section{Conclusions}

Pollen grain morphological attributes make it possible to isolate one ( $R$. gallica) out of 16 examined rose species. $R$. gallica is distinguished for the highest length values of polar and equatorial axes as well as the length of ectocolpi. The obtained results failed to corroborate diagnostic significance of exine sculpture and operculum both at the level of species and section. The examined features of exine did not allow the identification of individual species, although it was possible to distinguish groups of species of similar exine structure. The examined roses were assigned to four types of exine structure distinguished by Ueda [38]. Majority of the investigated roses had operculum of similar structure. All the examined species were assigned to the R. canina operculum type. Bearing in mind the above, it can be said that pollen grain morphology can only be used as an auxiliary attribute for the diagnostication of the examined Rosa genus species and sections.

The distribution of the examined species on the dendrogram corroborates only to a limited extent the division of the Rosa genus into sections currently adopted in taxonomy [5]. In addition, it only slightly reflects consanguinity relationships between species from the section Caninae described by Zieliński [7] and Henker [5].

\section{Acknowledgements}

The author would like to thank the following persons for help in research work, the team of workmen of the Institute of Botany of Vienna University, especially Prof. M. Hesse and PhD H. Halbritter, Prof. J. Zieliński (Institute of Dendrology of Polish Academy of Sciences, Kórnik), Prof. R. Popek (Pedagogical University of Cracow), Prof. K. Tobolski (Adam Mickiewicz University, Poznań), Prof. D. J. Gwiazdowicz, PhD A.M. Jagodziński and PhD J. Lira (Poznań University of Life Sciences). The work was supported by the State Committee for Scientific Research (KBN) grant No. 2 PO4C 08430.

\section{Supplementary material}

The following supplementary material for this article is available online at https://pbsociety.org.pl/journals/index.php/ asbp/rt/suppFiles/asbp.2011.031/0: 
1. Tab. S1. Numeral characteristics of features of studied pollen grains.

\section{References}

1. Klaštersky I. Rosa L. In: Tutin T, Heywood V, Burges N, Moore D, Valentine D, Walters S, et al., editors. Flora Europaea. Cambridge: Cambridge University Press; 1968. p. 25-32. (vol 2).

2. Hutchinson J. The genera of flowering plants. Oxford: Oxford University Press; 1964. (vol 1).

3. Zieliński J. Genus Rosa L. In: Jasiewicz A, editor. Flora Polski. Rośliny naczyniowe. Warszawa: Polish Scientific Publishers PWN; 1987. p. 7-49.

4. Nilsson O. Rosa L. In: Davis PH, editor. Flora of Turkey and the East Aegean Islands. Edinburgh: Edinburgh University Press; 1997. p. 106-128. (vol 4).

5. Henker H. Rosa L. In: Conert HJ, Jager EJ, Kadereit JW, Schulze-Motel W, Wagenitz W, Weber HE, editors. Hegi, Illustrierte flora von Mitteleuropa. Berlin: Blackwell Wissenschafts-Verlag; 2000. p. 3-108. (vol 4 pt 2C).

6. Kalkman C. Rosaceae. In: Kubitzki K, editor. The families and genera of vascular plants. Berlin: Springer; 2004. p. 386-443. (vol 6).

7. Zieliński J. Studia nad rodzajem Rosa L. - systematyka sekcji Caninae DC em Christ. Arboretum Kórnickie. 1985;30:3-109.

8. Popek R. Biosystematic studies of the genus Rosa L. in Poland and neighboring countries. Kraków: Polish Scientific Publishers PWN; 1996. (Prace Monograficzne; vol 218).

9. Gustafsson $\ddot{A}$. The constitution of the Rosa canina complex. Hereditas. 1944;30(3):405-428. doi:10.1111/j.1601-5223.1944.tb02738.x.

10. Klášterská I. New phenomena during meiosis in the genus Rosa. Hereditas. 1971;67(1):55-63. doi:10.1111/j.1601-5223.1971.tb02358.x.

11. Crépin F. Recherches sur l'etat du développement des grains de pollen dans diverses especes du genre Rosa. Bull Soc Roy Bot Belgique. 1889;28:14-125.

12. Cole RD. Imperfection of pollen and mutability in the genus Rosa. Bot Gaz. 1917;63(2):110-123.

13. Erlanson E. Pollen analysis for rose breeders. Am Rose Ann. 1934;19:63-68.

14. Flory WS. Pollen condition in some species and hybrids of Rosa with a consideration of assosiated phylogenetic factors. Va J Sci. 1950;1:11-59.

15. Mameli Calvino E. Ricerche sul polline del genere Rosa. Ann Sper Agrar. 1950;2:377-407.

16. Erdtman G. Pollen morphology and plant taxonomy: Angiosperms. Stockholm: Almqvist \& Wiksell; 1952. (vol 1).

17. Erdtman G, Berglund B, Praglowski J. An introduction to a Scandinavian pollen flora. Stockholm: Almqvist \& Wiksell; 1961.

18. Teppner H. Zur Kenntnis der Gattung Waldsteinia L. Phyton. 1966;11(3-4):224-238.

19. Reitsma TJ. Pollen morphology of some European Rosaceae. Acta Bot Neerl. 1966;15:290-379.

20. Heusser CJ. Pollen and spores of Chile. Tucson AZ: University of Arizona Press; 1971.

21. Stachurska A, Sadowska A, Kuszell T. The palynological card index of Polish plants. Opol Tow Przyj Nauk. 1974-1975;14-15:214-223.
22. Stachurska A, Sadowska A, Kuszell T. The palynological card index of Polish plants. Opol Tow Przyj Nauk. 1976;16:224-233.

23. Jičínska D. Diversity of pollination in some Rosa species. Preslia. 1975;47:267-274.

24. Končalova MN. Studies in rose pollen I. In vitro germination of pollen grains of Rosa hugonis. Preslia. 1975;47:22-25.

25. Jičínska D, Konalová MN, Sýkorová O. Studies in rose pollen III. Pollen viability and germinability in eight Czechoslovak Rosa species. Preslia. 1976;48:347-353.

26. Kuprianowa LA, Alyoshina LA. Pollen dicotyledonarum florae partis Europeae URSS. Lamiaceae-Zygophyllaceae. Leninigrad: Komorovii Institutum Botanicum. Academia Scientiarum USSR; 1978.

27. Eide F. Key for northwest european rosaceae pollen. Grana. 1981;20(2):101-118. doi:10.1080/00173138109427651.

28. Katiyar K. Studies in the pollen morphology of Rosales. New Delhi: Today \& Tomorrow's Printers \& Publishers; 1982.

29. Pearson HM, Harney PM. Pollen viability in Rosa. J Hortic Sci. 1984;19(5):710-711.

30. Fedoronchuk MM, Savitsky VD. Comparative and morphological analysis of pollen for genera of the family Rosaceae Juss. of the Ukrainian flora. Ukr Bot Zh. 1987;44(2):32-38.

31. Savitsky VD, Dubovik OM, Fedoronchuk MM. Pollen morphological diversity of the genus Rosa L. in Ukrainian flora. Ukr Bot Zh. 1987;43(1):36-41.

32. Faegri K, Iversen J. Textbook of pollen analysis. Chichester: Wiley and Sons; 1989.

33. Gonzalez Romano ML, Candau PA. Contribución a la palinología de Rosaceae. Acta Bot Malacit. 1989;14:105-116.

34. Ueda Y, Hirata M. Pollen fertility in Roses. Jap J Palynol. 1989;35(2):1-7.

35. Ueda Y, Tomita H. Morphometric analysis of pollen exine patterns in roses. J Japan Soc Hort Sci. 1989;58(1):211-220.

36. Hebda RJ, Chinnappa CC. Studies on pollen morphology of Rosaceae in Canada. Rev Palaeobot Palynol. 1990;64(14):103-108. doi:10.1016/0034-6667(90)90123-Z.

37. Moore P, Webb JA, Collinson ME. Pollen analysis. 2nd ed. Oxford: Blackwell Scientific Publications; 1991.

38. Ueda Y. Pollen surface morphology in the genus Rosa and related genera. Jap J Palynol. 1992;38(2):94-105.

39. Jones GD, Bryant VM, Lieux MH, Jones SD, Lingren PD. Pollen of the Southeastern United States: with emphasis on melissopalynology and entomopalynology. American Association of Stratigraphic Palynologists Foundation; 1995. (AASP contributions series).

40. Zhou LH, Wie ZX, Wu ZY. Pollen morphology of Rosoideae (Rosaceae) of China. Acta Bot Yunnan. 1999;21(4):455-460.

41. Jacob Y, Pierret V. Pollen size and ploidy level in the genus Rosa. Acta Hortic. 2000;508:289-292.

42. Beug HJ. Leitfaden der Pollenbestimmung: für Mitteleuropa und angrenzende Gebiete. München: Pfeil; 2004.

43. Shinwari MI, Khan MA. Pollen morphology of wild roses from Pakistan. Hamdard Med. 2004;47(4):5-13.

44. Wrońska-Pilarek D, Boratyńska K. Pollen morphology of Rosa gallica L. Rosaceae L. from southern Poland. Acta Soc Bot Pol. 2005;74(4):297-304.

45. Wrońska-Pilarek D, Lira J. Pollen morphology of Polish species of the genus Rosa L. I. Rosa pendulina L. Dendrobiology. 2006;55:65-73.

46. Wrońska-Pilarek D, Jagodziński A. Pollen morphological variability of Polish native species of Rosa L. (Rosaceae). 
Dendrobiology. 2009;62:71-82.

47. Wodehouse RP. Pollen grains their structure, identification and significance in science and medicine. New York: McGraw Hill; 1935.

48. Ueda Y, Okada Y. Discrimination of rose cultivar groups by pollen surface structure. J Hortic Sci. 1994;69(4):601-607.

49. Wrońska-Pilarek D. Pollen morphology of the Polish species of the genus Ribes L. Acta Soc Bot Pol. 1998;67(3-4):275-285.

50. Punt W, Hoen P, Blackmore S, Nilsson S, Lethomas A. Glossary of pollen and spore terminology. Rev Palaeobot Palynol. 2007;143(1-2):1-81. doi:10.1016/j. revpalbo.2006.06.008.

51. Hesse M, Halbritter H, Weber M, Buchner R, Frosch-Radivo A, Ulrich S. Pollen terminology: an illustrated handbook. Vienna: Springer; 2009.

52. Fogle HW. Identification of clones within four tree species by pollen exine patterns. J Amer Soc Hort Sci.
1977;102:552-560.

53. Matsuta N, Omura M, Akihama T. Difference in micromorphological pattern on pollen surface of Japanese Pear cultivars. Jpn J Breed. 1982;32(2):123-128. doi:10.1270/ jsbbs1951.32.123.

54. Marcucci M, Sansavini S, Ciampolini F, Cresti F. Distinguishing apple clones and cultivars by surface morphology and pollen physiology. J Amer Soc Hort Sci. 1984;109:10-19.

55. Hebda RJ, Chinnappa CC, Smith BM. Pollen morphology of the Rosaceae of Western Canada. Grana. 1988;27(2):95113. doi:10.1080/00173138809432836.

56. Hebda RJ, Chinnappa CC. Studies on pollen morphology of Rosaceae. Acta Bot Gall. 1994;141:183-193.

57. Menge U. Identifizierung von Rosensorten anhand von Pollenoberflachen mustern. Gartenbauwissenschaft. 1985;50(1):1-9. 